\title{
Activation of Toll-Like Receptor 3 Induces Interleukin-1 Receptor Antagonist Expression by Activating the Interferon Regulatory Factor 3
}

\author{
Yang Liu ${ }^{a, b}$ Chun-Fen Mo ${ }^{a, b}$ Xing-Yan Luo ${ }^{a, b}$ Hua Lic Hui-Jie Guo ${ }^{a, b}$ \\ Hai Sun ${ }^{a, b}$ Song Hu ${ }^{a, b} \quad$ Li-Mei Li ${ }^{a, b}$ Yan-Tang Wang ${ }^{a, b} \quad$ Shu-Xia Yang ${ }^{a, b}$ \\ Shan Chang ${ }^{d}$ Qiang Zou ${ }^{a, b}$ \\ a Department of Immunology, School of Basic Medical Sciences, Chengdu Medical College, Chengdu, PR China; \\ ${ }^{b}$ Center of Science and Research, Chengdu Medical College, Chengdu, PR China; ${ }^{C}$ Cancer Center, Chengdu Military

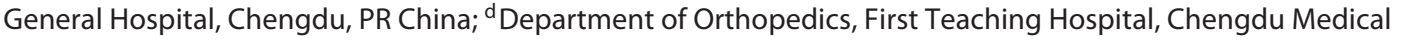 \\ College, Chengdu, PR China
}

\section{Keywords \\ Poly $(\mathrm{l}: \mathrm{C}) \cdot$ Toll-like receptor $3 \cdot$ Interleukin-1 receptor antagonist $\cdot$ Interferon regulatory factor $3 \cdot$ Human fibroblast-like synoviocytes}

\begin{abstract}
Toll-like receptor 3 (TLR3) is a sensor of endogenous cell necrosis during the process of acute inflammation. Interleukin (IL)-1 receptor antagonist (IL-1Ra) is an anti-inflammatory cytokine and can negatively regulate the pathogenesis of inflammation. However, whether and how activation of TLR3 can regulate IL-1Ra expression has not been clarified. Here, we show that poly $(\mathrm{I}: \mathrm{C})$ induces IL-1 Ra expression in primarily cultured human fibroblast-like synoviocytes and other types of cells. Induction of IL-1Ra by poly(I:C) was dependent on TLR3, but was independent of melanoma differentiationassociated protein 5 or retinoic acid-inducible gene I. Interferon regulatory factor 3 (IRF3) directly binds to the IL-1Ra promoter and promotes IL-1Ra expression in response to poly $(\mathrm{l}: \mathrm{C})$ stimulation. Induction of IL-1Ra by poly(I:C) was
\end{abstract}

Y.L., C.-F.M., and X.-Y.L. contributed equally to this work.

karger@karger.com www.karger.com/jin

Karger"
(C) 2019 The Author(s)

Published by S. Karger AG, Basel

Karge

Open access

This article is licensed under the Creative Commons AttributionNonCommercial-NoDerivatives 4.0 International License (CC BYNC-ND) (http://www.karger.com/Services/OpenAccessLicense) Usage and distribution for commercial purposes as well as any distribution of modified material requires written permission. abolished by the inhibition of the NF-KB signaling, attenuated by the inhibition of the PI3K-Akt signaling, enhanced by inhibition of the ERK $1 / 2$ or MSK $1 / 2$ activation, but was independent of the $\mathrm{p} 38 \mathrm{MAPK}$ signaling. Treatment with poly $(\mathrm{l}: \mathrm{C})$ or Sendai virus elevated the levels of serum IL-1Ra in wildtype, but not in $\mathrm{TLR3}^{-/-}$or IRF3 ${ }^{-1-}$ mice. Our findings may provide new insights into the intrinsic anti-inflammatory function of TLR3 and double-stranded RNA-induced IL-Ra expression by TLR3 and its regulation.

(c) 2019 The Author(s)

Published by S. Karger AG, Basel

\section{Introduction}

Toll-like receptor 3 (TLR3) is a member of the TLR family, and is expressed onto the membranes of endosomes. TLR3 can recognize double-stranded RNA (dsRNA), the major component in many viruses, and plays a pivotal role in innate immune responses during virus infection $[1,2]$, although melanoma differentiation-asso-

Dr. Qiang Zou

Department of Immunology, School of Basic Medical Sciences

Chengdu Medical College No. 783, Xindu Avenue

Chengdu, Sichuan 610500 (PR China)

E-Mail qiangzou99@gmail.com

Prof. Shan Chang

Department of Orthopedics, First Teaching Hospital

Chengdu Medical College

Chengdu, Sichuan 610500 (PR China)

E-Mail changshancmc@ tom.com 
ciated protein 5 (MDA5) and retinoic acid-inducible gene I (RIG-I) are required for antiviral response by recognized intracytoplasmic dsRNA [3-5]. Recent studies reveal the detrimental contribution of TLR3 in viral pathogenesis [6], indicating that the function of TLR3 may not limit in anti-virus. TLR3 can also recognize endogenous RNA released from necrotic cells or damage tissues and initiate inflammatory responses [7-10]. Activation of TLR3 induces production of proinflammatory cytokines $[1,11]$, which is associated with the development and progression of autoimmune disease, such as rheumatoid arthritis (RA) [7]. However, activation of TLR3 can protect against cardiovascular diseases by inducing anti-inflammatory interleukin (IL)-10 production [12], which in turn activates the STAT3 to protect against oxidative stress [13-15]. In contrast, another study reported that TLR3 activation protected against acute colitis, independent of IL-10 [16]. Hence, the potential mechanisms underlying the biological function of TLR3 activation in regulating inflammation have not been clarified.

IL-1 is an important proinflammatory cytokine and is crucial for responding to infection [17]. IL-1 receptor antagonist (IL-1Ra) is a member of the IL-1 family, and can bind to the IL- 1 receptor to block the IL-1R-related signaling [18]. The balance of IL- 1 and IL-1Ra is crucial for regulating the pathogenesis of autoimmune diseases $[18,19]$. Indeed, the IL-1 $a$ transgenic mice spontaneously develop symptoms similar to arthritis [20] and IL-1 $\beta^{-/-}$mice are less susceptible to collagen-induced arthritis [21]. In contrast, the IL-1 $\mathrm{Ra}^{-/-}$mice are especially susceptible to develop RA $[22,23]$. More importantly, individuals with deficiency of the IL-1Ra develop chronic recurrent multifocal osteomyelitis and their symptoms include synovitis, acne, pustulosis, hyperostosis and osteitis [24, 25]. Treatment with recombinant human IL-1Ra (anakinra) benefits patients with arthritis [26], particularly for those with systemic-onset juvenile idiopathic arthritis. Previous studies have shown that treatment with lipopolysaccharides (LPS), IFN- $\beta$, or leptin can induce IL-1Ra expression in different types of cells [27-29]. However, whether activation of TLR3 by dsRNA can induce IL-1Ra expression and its mechanisms have not been explored.

Engagement of TLR3 by its ligand can activate the TRIF-dependent signaling by recruiting TRAF3 that activates the kinases TBK1 and IKKi to phosphorylate and activate interferon regulatory factor 3 (IRF3), leading to type I IFN production [30]. Simultaneously, the TRIFdependent signaling can also activate TRAF6 that activates TAK1 in complex with TAB2 and TAB3, leading to activation of the NF- $\mathrm{KB}$ and MAPK signaling [31, 32]. The signal networks can crosstalk with the PI3K/Akt, ERK, MSK, and P38 MAPK signaling [1, 2, 11]. Previous studies have shown that TLR4 activation-related IRF3 and PI3K/Akt signaling are crucial for IL-1Ra expression in microglia [33]. However, it is still unclear whether TLR3-related signaling regulates the TLR3 activation-related IL-1Ra expression in primarily cultured human and mouse fibroblast-like synoviocytes (FLS).

In the present study, we found that IL-1Ra was induced by poly(I:C) in primarily cultured human FLS, articular chondrocytes (AC), nucleus pulposus cells (NPC), and mouse FLS, peritoneal macrophages (PM), and dendritic cells (DC). Induction of IL-1Ra by poly(I:C) was dependent on TLR3 activation, but was independent of MDA5 or RIG-I. Activation of TLR3-related signaling directly induced IL-1Ra mRNA transcription, independent of poly(I:C)-induced IFN- $\beta$ and proinflammatory cytokines. The potential regulatory signaling of poly(I:C) treatment to activate TLR3 on IL-1Ra expression was further investigated in vitro cellular and in vivo animal models. Our results indicate the intrinsic anti-inflammatory function of TLR3 and its regulatory signaling pathway.

\section{Materials and Methods}

Mice

TLR3 $^{-/-}$C57BL/6J mice were obtained from Huaxi Laboratory Animal Center of Sichuan University (Chengdu, China). IRF- $3^{-/}$ C57BL/6J mice were purchased from the RIKEN BioResource Center (RBRC00858) through the Model Animal Research Center of Nanjing University (Nanjing, China). Mice were housed in a specific pathogen-free facility with free-access to normal chaw and water. All animal experiments were approved by the Animal Ethics Committee of Chengdu Medical College.

\section{Primary Cell Culture}

The synovial, cartilage, and skin tissues were obtained from patients with RA, avascular necrosis of the femoral head or a bone fracture during the surgical knee replacement. Nucleus pulposus tissues were obtained from patients with the intervertebral disc degeneration during the surgery. The fresh synovial tissues were minced and digested with $0.5 \mathrm{mg} / \mathrm{mL}$ collagenase VIII (Sigma-Aldrich, St. Louis, MO, USA) at $37^{\circ} \mathrm{C}$ for $2 \mathrm{~h}$. The cartilage tissues were first digested with $10 \mathrm{mg} / \mathrm{mL}$ protease (Sigma-Aldrich) at $37^{\circ} \mathrm{C}$ for $1 \mathrm{~h}$ and then digested with $3.5 \mathrm{mg} / \mathrm{mL}$ collagenase II (Worthington, NJ, USA) at $37^{\circ} \mathrm{C}$ for $4 \mathrm{~h}$. The skin tissues were digested with dispase II (Roche Applied Science, Indianapolis, IN, USA) at $4{ }^{\circ} \mathrm{C}$ for $10 \mathrm{~h}$. Subsequently, the epidermis layer of the skin was removed, and the dermis layer was digested with $1 \mathrm{mg} / \mathrm{mL}$ collagenase IV (Invitrogen, Carlsbad, CA, USA) at $37^{\circ} \mathrm{C}$ for $2 \mathrm{~h}$. The nucleus pulposus tissues were digested with collagenase II at $37^{\circ} \mathrm{C}$ for $4 \mathrm{~h}$.

After digestion, FLS [34], AC [35], dermal fibroblasts (DF) [36], and NPC [37] in the digested tissues were isolated and cul- 
tured in DMEM (Invitrogen) supplemented with 10\% FBS (InvivoGen, San Diego, CA, USA) as previously described. Human bone marrow mesenchymal stem cells (BMSC) were generated from marrow aspirates, as described previously [38]. Human T cells and B cells were isolated from human peripheral blood mononuclear cells by negative selection using the Pan T cell Isolation Kit II Human or the B cell Isolation Kit II Human (Miltenyi Biotec, Bergisch Gladbach, Germany), as previously described [39]. Mouse FLS were derived from the ankle joints of C57BL/6J mice at 10-12 weeks old. The isolated primary FLS cells were passaged several times before use, displayed typical FLS morphology, and were positive for VCAM-1 expression [40]. The DC from C57BL/6] mice at 6-8 weeks of age were generated from BM progenitors as described previously [41]. Mouse PM was collected from female C57BL/6J mice by peritoneal lavage with ice-cold PBS.

\section{Treatment}

FLS were stimulated in triplicate with a TLR3 agonist, poly(I:C)HMW $20 \mu \mathrm{g} / \mathrm{mL}$ (InvivoGen) for 1, 3, 8, 24, 48, 72, or $96 \mathrm{~h}$ and other types of cells were treated in triplicate with poly(I:C) for 24 $\mathrm{h}$. The different types of cells were treated in triplicate with a TLR1/2 agonist Pam3CSK4 (300 ng/mL), TLR2 agonist HKSA/ HKLM $\left(1 \times 10^{8}\right.$ cells $\left./ \mathrm{mL}\right)$, TLR4 agonist LPS $(10 \mu \mathrm{g} / \mathrm{mL})$, TLR5 agonist FLA-ST $(1 \mu \mathrm{g} / \mathrm{mL})$ and TLR6/2 agonist Pam2CSK4 (100 $\mathrm{ng} / \mathrm{mL}$, all from InvivoGen) for $24 \mathrm{~h}$.

In addition, some cells were pre-treated in triplicate with hydroxychloroquine sulfate $(10 \mu \mathrm{g} / \mathrm{mL}$, a TLR3 antagonist, SigmaAldrich), cycloheximide (10 $\mu \mathrm{g} / \mathrm{mL}$, Sigma-Aldrich), BX795 (1 $\mu \mathrm{M}$, an inhibitor of TBK1 and IKKe, Sigma-Aldrich), BMS-345541 (10 $\mu \mathrm{M}$, an inhibitor of IкB, Sigma-Aldrich), SB415286 (25 $\mu \mathrm{M}$, an inhibitor of GSK-3, Sigma-Aldrich), SB203580 (5 $\mu \mathrm{M}$, an inhibitor of the p38 MAPK, Sigma-Aldrich), PD184352 (2 $\mu \mathrm{M}$, an inhibitor of the MEK, Sigma-Aldrich), LY294002 (25 $\mu$ M, an inhibitor of PI3K, Promega, Madison, WI, USA), or SB747651A (10 $\mu$ M, an inhibitor of the MSK, R\&D, Abington, UK) for $1 \mathrm{~h}$ and stimulated with poly(I:C; $20 \mu \mathrm{g} / \mathrm{mL})$ for $8 \mathrm{~h}$ or $24 \mathrm{~h}$.

\section{Small Interfering RNA Transfection}

Human FLS were cultured in 6-well plates and when the cells reached at $80 \%$ of confluency, the cells were transfected in duplicate with individual types of siRNAs ( $25 \mathrm{pmol}$ ) for $48 \mathrm{~h}$ using lipofectamine RNAiMAX Reagent (Invitrogen), according to the manufacturers' instruction. The transfected siRNAs included siRNA specific for MDA5, also known as interferon induced with helicase C domain 1 (M-013041-00-0005), for RIG-I/ROBO3 (M-02650400-0005), for TLR3 (M-007745-00-0005) and for IRF3 (M-00687502-0005, siGENOME SMART pools; Dharmacon, Lafayette, CO, USA).

\section{Quantitative Real-Time PCR}

Total RNA was extracted from individual cell samples using the TRIZOL Reagent and reversely transcribed in cDNA using the PrimeScriptTM RT reagent Kit (TaKaRa, Dalian, China). The relative levels of target gene mRNA transcripts to the control $18 \mathrm{~S}$ rRNA and GAPDH were determined by quantitative real-time PCR using the FastStart Universal Probe Master (ROX) mix (Roche Applied Science), specific primers and the Universal Probe Library (UPL) Set in LightCycler System (Roche Applied Science). The PCR reactions were performed in duplicate at $95^{\circ} \mathrm{C}$ for $15 \mathrm{~s}$ and subjected to 40 cycles of $95^{\circ} \mathrm{C}$ for $15 \mathrm{~s}$ and $60^{\circ} \mathrm{C}$ for $1 \mathrm{~min}$.
The sequences of primers were: human IL-1Ra forward: CCCATGGCTTTAGCTGACTT, reverse:TCAGCATTGTCTTCACCTTCTC, probe: UPL 10; human IFN- $\beta$ forward: CGACACTGTT CGTGTTGCTCA, reverse: GAAGCACAACAGGAGAGCAA, probe: UPL 25; human IRF3 forward: AAGGAAGGAGGCGTGTTTG, reverse: TTCCTTCCGTGAAGGTAATCA, probe: UPL 57; human TLR3 forward: AGAGTTGTCATCGAATCAAATTAAAG, reverse: AATCTTCCAATTGCGTGAAAA, probe: UPL 80; human MDA-5 forward: CTCAGGCCTTACCAAATGGA, reverse: CCTGTAGGGAGGCAGATGAT, probe: UPL 20; human RIG-I forward: CTCTTGGGCTTCAACTCCTC, reverse: CTACCCTTGACCCGTTGAGA, probe: UPL 16; mouse TLR3 forward: GATACAGGGATTGCACCCATA, reverse: TCCCCCAAAGGAGTACATTAGA, probe: UPL 26; mouse IRF3 forward: ATGGCTGACTTTGGCATCTT, reverse: CGTCCGGCTTATCCTTCC, probe: UPL 29. The data were normalized to $18 \mathrm{~S}$ rRNA and GAPDH and analyzed by $2^{-\Delta \Delta C t}$.

\section{Enzyme-Linked Immunosorbent Assays}

The cell cultural supernatants were collected and the levels of human IL-1Ra, IFN- $\beta$, IL-6, and IL-10, and mouse IL-1Ra and IFN- $\beta$ were measured by ELISA using specific kits (eBioscience, San Diego, CA, USA), in accordance with the standard curves established using recombinant cytokines provided.

\section{Immunoblotting}

The cells were lyzed in lysis buffer (Millipore, Bedford, MA, USA) and centrifuged. The cell lysates $(20 \mu \mathrm{g} /$ lane $)$ were separated SDS-polyacrylamide gel electrophoresis on $10 \%$ gels and transferred onto polyvinylidene difluoride membranes (Millipore). The membranes were blocked with 5\% BSA and were probed overnight at $4{ }^{\circ} \mathrm{C}$ with antibodies against IL-1Ra, I $\kappa \mathrm{B} \alpha, \mathrm{p}-\mathrm{I} \kappa \mathrm{B} \alpha$, Akt, p-Akt, GSK3 $\beta$, p-GSK3 $\beta$, ERK1/2, p-ERK1/2, CREB, p-CREB, p38 AMPK, p-p38 MAPK, or GAPDH (Cell Signaling Technology, Beverly, MA, USA). After being washed, the bound antibodies were detected with horseradish peroxidase-conjugated second antibodies (Santa Cruz Biotech, Santa Cruz, CA, USA) and visualized using the enhanced chemiluminescence reagents (Millipore). The relative levels of target protein to the control GAPDH were analyzed by densitometric scanning using the ImageJ software.

\section{Chromatin Immunoprecipitation Assay}

The ChIP assay was performed using the ChIP Assay Kit (Beyotime, China) following the manufacturer's guidelines. Poly(I:C)treated cells were cross-linked with $1 \%$ formaldehyde solution for $10 \mathrm{~min}$ at room temperature and quenched with $125 \mathrm{~mm}$ glycine. DNA fragments ranging from 200 to 500 bp were obtained by ultrasonication. Then the lysate was immunoprecipitated with antiIRF3 or IgG antibodies. Immunoprecipitated DNAs were analyzed by PCR. The size and purity of the PCR products were checked by analyzing the products with gel electrophoresis in $2 \%$ agarose gel. The sequences of primers that IRF3 binds to IL-1Ra: forward: CATTATTCTGCTTACCACAGGGGACC, reverse: AGTTCTGCCCTTTTTCTAACCCCAC.

\section{IL-1Ra Detection in vivo}

Wild-type, TLR3 ${ }^{-/-}$and IRF3 ${ }^{-/-}$mice were treated intraperitoneally with poly(I:C; $10 \mathrm{mg} / \mathrm{kg}$ in sterile endotoxin-free physiological saline) or Sendai virus (100 HA units $/ \mathrm{mL}$ ) for $24 \mathrm{~h}$. Sendai virus (ATCCVR-105) was obtained from the American Type Cul- 
ture Collection (Rockville, MD, USA). Their blood samples were collected and the levels of serum IL-1Ra in individual mice were determined by ELISA.

\section{Statistical Analysis}

Data are expressed as mean \pm SEM. The difference among groups was determined by one-way analysis of variance and post hoc Dunnett comparisons using the SPSS software. A $p$ value of $<0.05$ was considered statistically significant.

\section{Results}

\section{Poly(I:C) Induces IL-1Ra Expression in Several}

Types of Cells

Since TLR7, 8, and 9 are not expressed in FLS [7], the effect of TLR1-6 activation on IL-1Ra expression was tested in human FLS by ELISA. As shown in Figure 1a, high levels of IL-1Ra were detected in the FLS that had been treated with poly(I:C), a TLR3 agonist, and much lower levels of it in the LPS-treated cells. However, no detectable IL-1Ra was detected in the cells that had been treated with agonists for TLR1, 2, 5, and 6. Furthermore, treatment with different doses of poly(I:C) or LPS stimulated IL-1Ra expression in a dose-dependent manner and the levels of IL-1Ra stimulated by poly(I:C) were severalfold higher than that by LPS (Fig. 1b). In addition, treatment with poly(I:C) stimulated high levels of IL-1Ra in the primarily cultured FLS from 12 patients with different types of diseases as well as in MH7A cells (Fig. 1c, d). Quantitative RT-PCR indicated that IL-1Ra mRNA transcripts were detected at $8 \mathrm{~h}$ and peaked at $48 \mathrm{~h}$ post stimulation, and then decreased gradually (Fig. 1e). The IL-
$1 \mathrm{Ra}$ protein levels were detected at $24 \mathrm{~h}$ and then increased gradually up to $96 \mathrm{~h}$ after stimulation (Fig. 1f).

Given that TLR3 is expressed by various types of cells, such as DC, macrophages, fibroblasts, epithelial cells, and neurons [1], we further tested the effect of poly(I:C) treatment on IL-1Ra expression by ELISA. We found that treatment with poly(I:C) induced IL-1Ra expression in FLS, some types of immune cells and non-immune cells, including AC, NPC, PM, and DC, but not in T cells, B cells, DF, BMSC, WI-38, MRC-5, NCI-H358, NCI-H460, SH-SY5Y, and BV2 (Fig. 1d). Moreover, following poly(I:C) stimulation, IL-1Ra was detected by Western blot in human FLS (Fig. 1g). However, we found that treatment with poly(I:C) stimulated high levels of IL-1Ra, but not IL-10 in human FLS (Fig. 1h). Collectively, activation of TLR3 by poly(I:C) stimulated IL-1Ra expression in several types of cells.

\section{Induction of IL-1Ra by Poly(I:C) Is Dependent on TLR3 Activation}

MDA5 and RIG-I also recognized dsRNA. To determine IL-1Ra induction by poly(I:C) was dependent on activation of TLR3 but not MDA5 and RIG-I, primarily cultured human FLS were pre-treated with the specific siRNA of TLR3, MDA5 or RIG-I for $48 \mathrm{~h}$, and stimulated with or without poly(I:C) for $24 \mathrm{~h}$. Our result showed, knockdown of TLR3, MDA5, or RIG-I significantly reduced the levels of TLR3, MDA5, or RIG-I expression (Fig. 2a-c). It was interesting that knockdown of TLR3 significantly mitigated poly(I:C)-stimulated IL-1Ra expression (Fig. 2d), but knockdown of MDA5 or RIG-I failed to modulate poly(I:C)-stimulated IL-1Ra expres-
Fig. 1. Poly(I:C) induces IL-1Ra expression in several types of cells. Human FLS $\left(10^{5}\right.$ cells $\left./ \mathrm{mL}\right)$ were stimulated with the indicated TLR agonists, including Pam3CSK4, HKSA/HKLM, poly(I:C), LPS, FLA-ST, or Pam2CSK4 for $24 \mathrm{~h}$ (a). Human FLS were stimulated by poly(I:C; 100, 25, $6.3 \mu \mathrm{g} / \mathrm{mL})$ or LPS $(100,25,6.3 \mu \mathrm{g} / \mathrm{mL})$ for 24 h (b). Human FLS from 12 individuals with RA, femoral head necrosis or fracture were stimulated by poly(I:C) for $24 \mathrm{~h}$ (c). Human FLS $\left(10^{5}\right.$ cells $\left./ \mathrm{mL}\right)$, MH7A $\left(10^{5}\right.$ cells $\left./ \mathrm{mL}\right)$, AC $\left(5 \times 10^{5}\right.$ cells $\left./ \mathrm{mL}\right)$, NPC $\left(2 \times 10^{5}\right.$ cells $\left./ \mathrm{mL}\right)$, T cells $\left(10^{6}\right.$ cells $\left./ \mathrm{mL}\right)$, B cells $\left(10^{6}\right.$ cells/ $\mathrm{mL}), \mathrm{DF}\left(5 \times 10^{4}\right.$ cells $\left./ \mathrm{mL}\right)$, BMSC $\left(5 \times 10^{4}\right.$ cells $\left./ \mathrm{mL}\right)$, WI- 38 cells $\left(10^{5}\right.$ cells $\left./ \mathrm{mL}\right), \mathrm{MRC}-5$ cells $\left(2.5 \times 10^{5}\right.$ cells $\left./ \mathrm{mL}\right), \mathrm{NCI}-\mathrm{H} 358$ cells $\left(4 \times 10^{5}\right.$ cells $\left./ \mathrm{mL}\right)$, NCI-H460 cells $\left(4 \times 10^{5}\right.$ cells $\left./ \mathrm{mL}\right)$ and SH-SY5Y cells $\left(5 \times 10^{5}\right.$ cells $\left./ \mathrm{mL}\right)$, and mouse FLS $\left(10^{5}\right.$ cells $\left./ \mathrm{mL}\right), \mathrm{PM}\left(5 \times 10^{5}\right.$ cells $/ \mathrm{mL})$, DC $\left(5 \times 10^{5}\right.$ cells $\left./ \mathrm{mL}\right)$ and BV2 $\left(5 \times 10^{5}\right.$ cells $\left./ \mathrm{mL}\right)$ were stimulated by poly(I:C) for $24 \mathrm{~h}$ (d). Human FLS were stimulated by poly(I:C) for $3,8,24,48,72$ or $96 \mathrm{~h}$. The cells were harvested and the levels of IL-1Ra mRNA expression were measured by quantitative real-time PCR (e). Upregulation of IL-1Ra expression is compared with unstimulated cultures. The concentrations of IL$1 \mathrm{Ra}$ in the culture supernatants were measured by ELISA (f). The cells were harvested and the relative levels of cytoplasmic IL-1Ra expression were assessed by Western blot (g). Human FLS were stimulated by poly(I:C) for $24 \mathrm{~h}$ (h). The cells were harvested and the levels of IL-1Ra and IL-10 mRNA expression were measured by quantitative real-time PCR. Upregulation of IL-1Ra and IL-10 expression is compared with unstimulated cultures. The concentrations of IL-1Ra and IL-10 in the culture supernatants were measured by ELISA. Results are presented as mean \pm SEM $(n=5$ per group in $\mathbf{a}, \mathbf{b}, \mathbf{d}-\mathbf{f}, n=12$ per group in $\mathbf{c}$ ) from 3 separate experiments. ${ }^{*} p<0.05$ versus the group without poly(I:C). IL, interleukin; IL-1Ra, IL-1 receptor antagonist; LPS, lipopolysaccharides; AC, articular chondrocytes; NPC, nucleus pulposus cells; PM, peritoneal macrophages; DC, dendritic cells; FLS, fibroblast-like synoviocytes; DF, dermal fibroblasts; BMSC, bone marrow mesenchymal stem cells.

(For figure see next page.)
The Intrinsic Anti-Inflammatory

Function of TLR3
Innate Immun 2020;12:304-320

DOI: $10.1159 / 000504321$ 
sion (Fig. 2e, f). In addition, the primarily cultured FLS from wild-type and TLR $3^{-1-}$ mice (Fig. $2 \mathrm{~g}$ ) were stimulated with or without poly(I:C) for $24 \mathrm{~h}$. While poly(I:C) effectively stimulated IL-1Ra expression in FLS from wild-type mice, the same stimulation failed to enhance IL-1Ra expression in FLS from TLR3 ${ }^{-1-}$ mice (Fig. 2h). These independent lines of evidence demonstrated that induction of IL-1Ra expression by poly(I:C) was dependent on activation of TLR3-related signaling in FLS.
Induction of IL-1Ra by Poly(I:C)-Mediated TLR3 Activation Is Independent of IFN- $\beta$ and Proinflammatory Cytokines

Previous studies have shown that activation of TLR3 by poly(I:C) can induce IFN- $\beta$ and proinflammatory cytokines [42]. Accordingly, we determined the role of these cytokines on IL-1Ra expression induced by poly(I:C). First, the dynamics of IFN- $\beta$ and IL-1Ra mRNA transcription in the poly(I:C)-treated FLS were determined

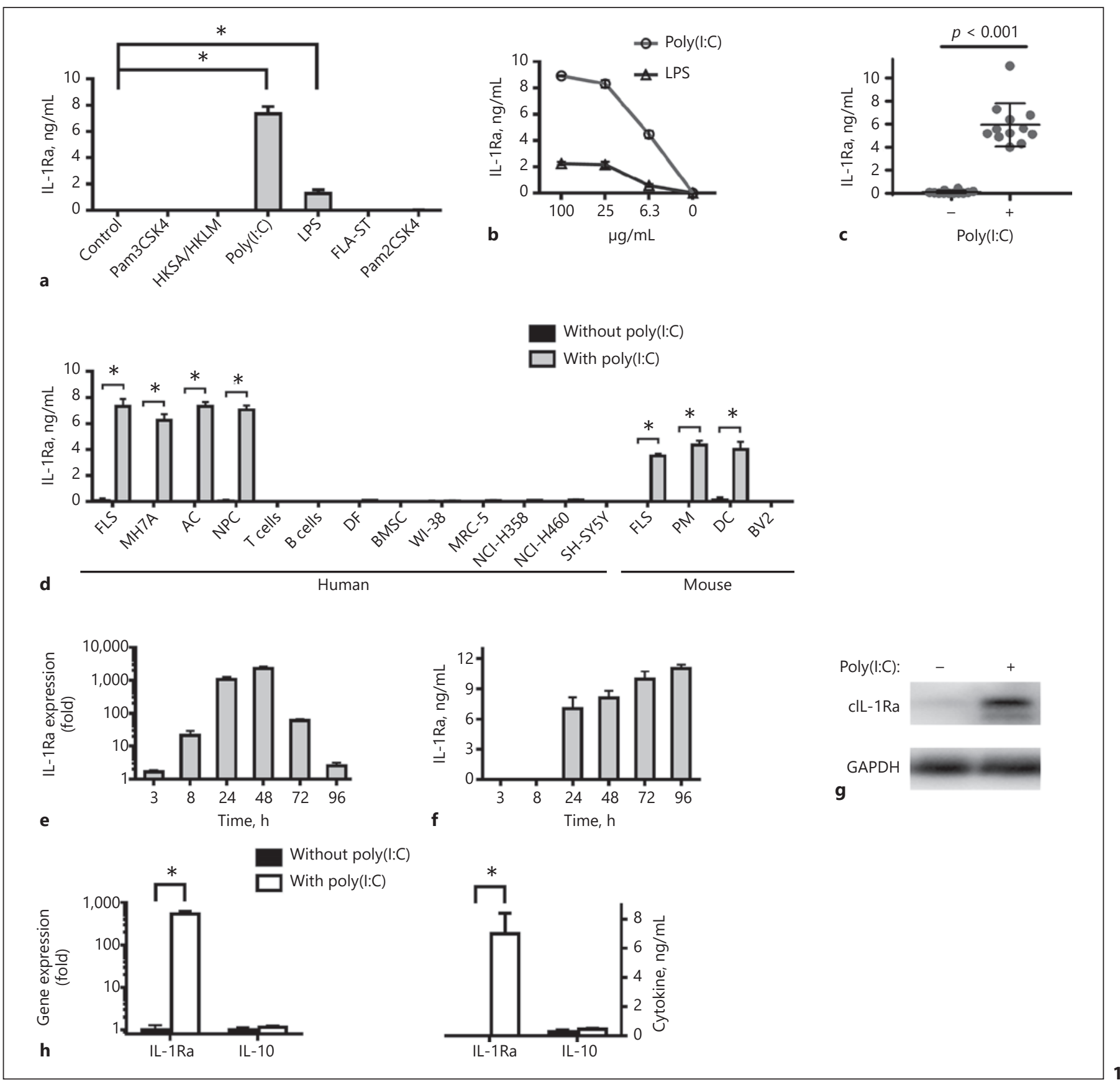



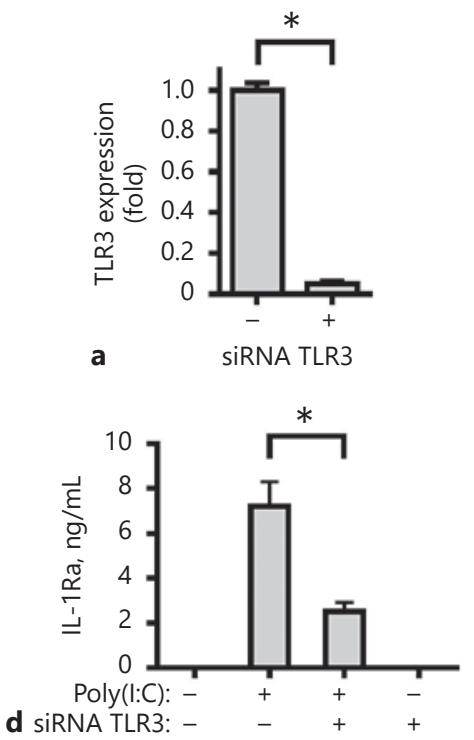

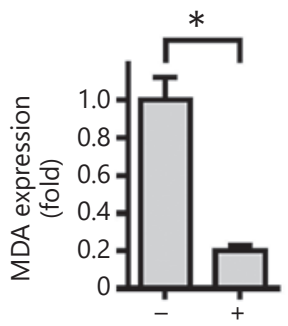

b

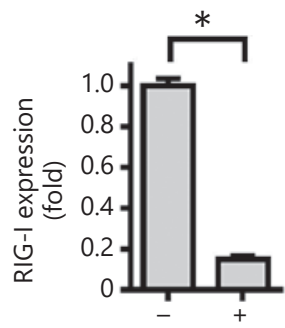

c
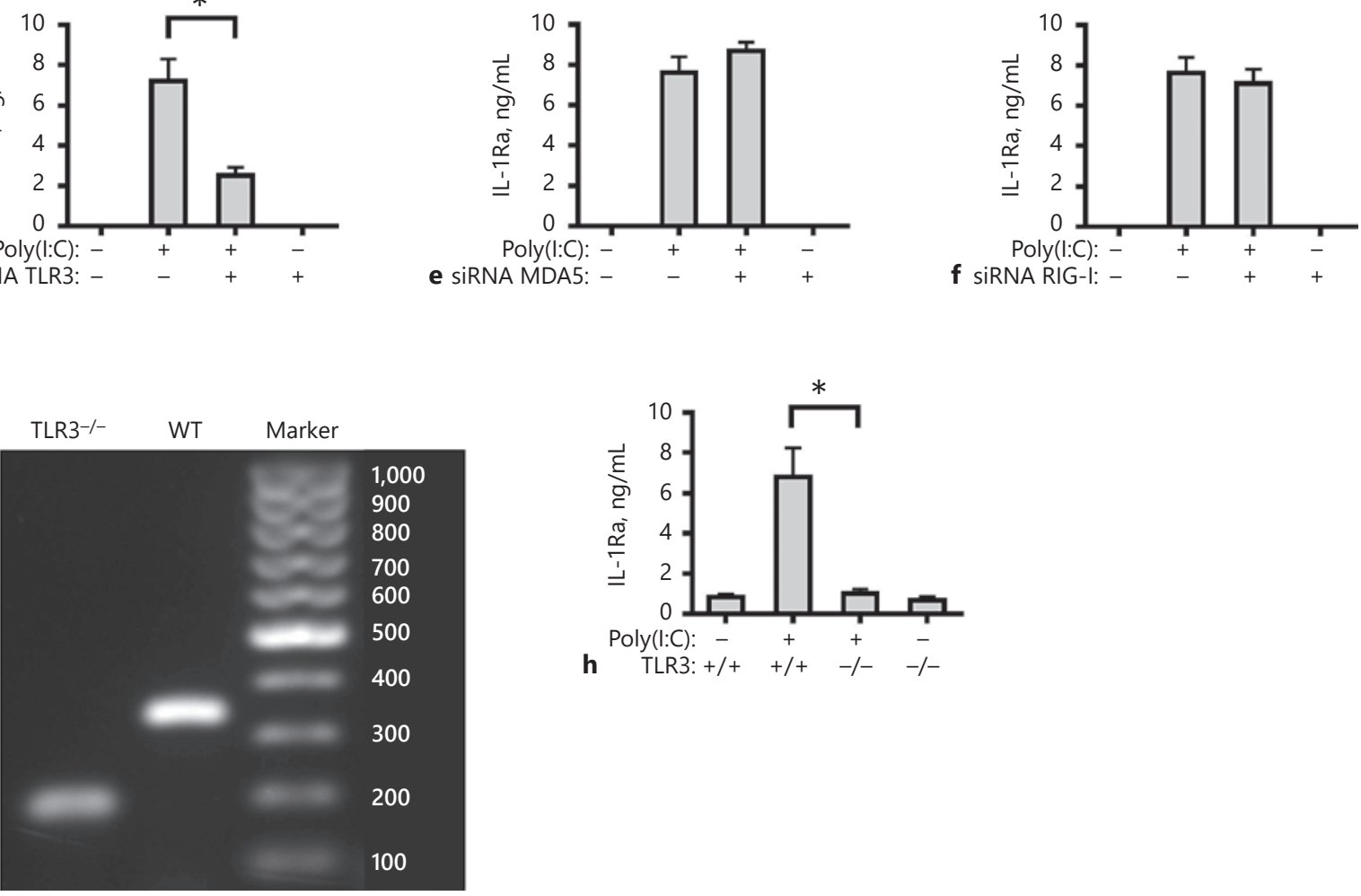

Fig. 2. Induction of IL-1Ra expression by poly(I:C) is dependent on the TLR3 activation. Human FLS were treated with siRNA TLR3 (a), siRNA MDA5 (b), siRNA RIG-I (c), or siRNA negative control (NC) for $48 \mathrm{~h}$. The cells were harvested and the levels of human TLR3, MDA5 and RIG-I mRNA expression were measured by real-time PCR. Downregulation of human TLR3, MDA5 and RIG-I expression are compared with siRNA NC group. Human FLS were pre-treated with siRNA TLR3 (d), siRNA MDA5 (e), siRNA RIG-I (f), or siRNA NC for $48 \mathrm{~h}$ and stimulated by poly(I:C) for $24 \mathrm{~h}$. The culture supernatants were harvested and

by quantitative real-time PCR (Fig. 3a). Treatment with poly(I:C) rapidly stimulated IFN- $\beta$ production, which peaked at $3 \mathrm{~h}$ post treatment and declined gradually. In contrast, the significantly increased levels of IL-1 Ra stimulated by poly(I:C) were detected at $8 \mathrm{~h}$ post treatment

The Intrinsic Anti-Inflammatory

Function of TLR3 the concentrations of IL-1Ra were determined with ELISA. WT (341bp) and TLR3 ${ }^{-1-}$ (208 bp) mice were identified by PCR (g). FLS $\left(10^{5}\right.$ cells $\left./ \mathrm{mL}\right)$ from WT or TLR $3^{-/-}$mice were stimulated by poly(I:C) for $24 \mathrm{~h}(\mathbf{h})$. The culture supernatants were harvested and the concentrations of IL-1Ra were determined with ELISA. Results are presented as mean \pm SEM ( $n=5$ per group) from 3 separate experiments. ${ }^{*} p<0.05$ versus the siRNA NC group without poly(I:C; a-c) or with poly(I:C; d-f, h). MDA5, melanoma differentiation-associated protein 5; RIG-I, retinoic acid-inducible gene I; IL-1Ra, IL-1 receptor antagonist; TLR3, toll-like receptor 3.

and peaked at $48 \mathrm{~h}$ post treatment. Hence, poly(I:C) stimulated IFN- $\beta$ expression much earlier than IL-1Ra, suggesting that IL-1Ra expression induced by poly(I:C) may be dependent on IFN- $\beta$. However, treatment with exogenous IFN- $\beta$ or combination with its specific antibodies 


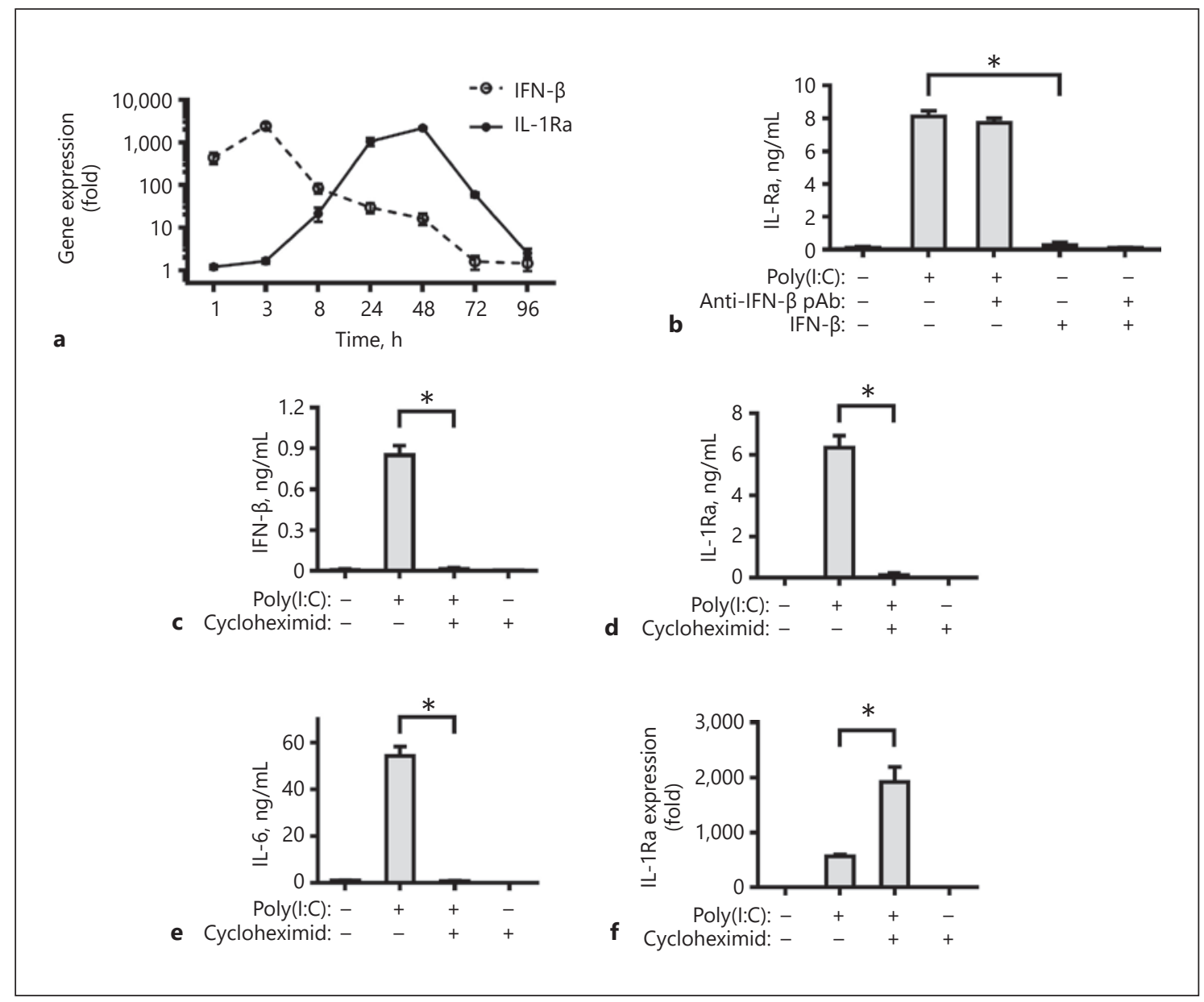

Fig. 3. Induction of IL-1Ra expression by poly(I:C)-mediated TLR3 activation is independent of IFN- $\beta$ and proinflammatory cytokines. Human FLS were stimulated by poly(I:C) for 1, 3, 8, 24, 48,72 , or $96 \mathrm{~h}$. The cells were harvested and the levels of IFN- $\beta$ and IL-1Ra mRNA expression were measured by real-time PCR (a). Human FLS were stimulated with poly(I:C), IFN- $\beta(10 \mathrm{ng} / \mathrm{mL})$ and/or anti-IFN- $\beta \mathrm{mAb}(10 \mu \mathrm{g} / \mathrm{mL})$ for $24 \mathrm{~h}(\mathbf{b})$. Human FLS were pre-treated with cycloheximide $(10 \mu \mathrm{g} / \mathrm{mL})$ for $1 \mathrm{~h}$ and stimulated by poly(I:C) for $24 \mathrm{~h}$. The concentrations of IFN- $\beta$ (c), IL-1Ra (b, d), and IL-6 (e) in the culture supernatants were determined with ELISA. The relative levels of IL-1Ra mRNA expression in different groups of cells were measured by real-time PCR (f). Upregulation of IL-1Ra expression is compared with the group without poly(I:C) and cycloheximide. Results are presented as mean \pm SEM $(n=5$ per group) from 3 separate experiments. ${ }^{*} p<0.05$ vs. the group with poly(I:C) and vehicle. IL, interleukin; IL-1Ra, IL-1 receptor antagonist. did not induce detectable IL-1Ra expression in FLS, while treatment with poly(I:C) in the presence of anti-IFN- $\beta$ failed to modulate the levels of IL-1Ra induced by poly(I:C) in FLS (Fig. 3b), indicated that induction of IL1 Ra expression by TLR3 activation was independent of IFN- $\beta$. To determine the role of proinflammatory cytokines on IL-1Ra induced by poly(I:C), FLS cells were treated with poly(I:C) in the presence or absence of cycloheximide, an inhibitor of protein synthesis [27]. We found that treatment with cycloheximide completely blocked the poly(I:C)-induced protein level of cytokine, including IFN- $\beta$, IL-6, and IL-1Ra protein (Fig. 3c-e), but did not reduce poly(I:C)-stimulated IL-1Ra mRNA transcription (Fig. 3f). It is interesting IL-1Ra mRNA transcription was significantly increased after cycloheximide treatment. Thus, induction of IL-1Ra expression by TLR3 activation was independent of poly(I:C)-induced IFN- $\beta$ and proinflammatory cytokines in FLS. 

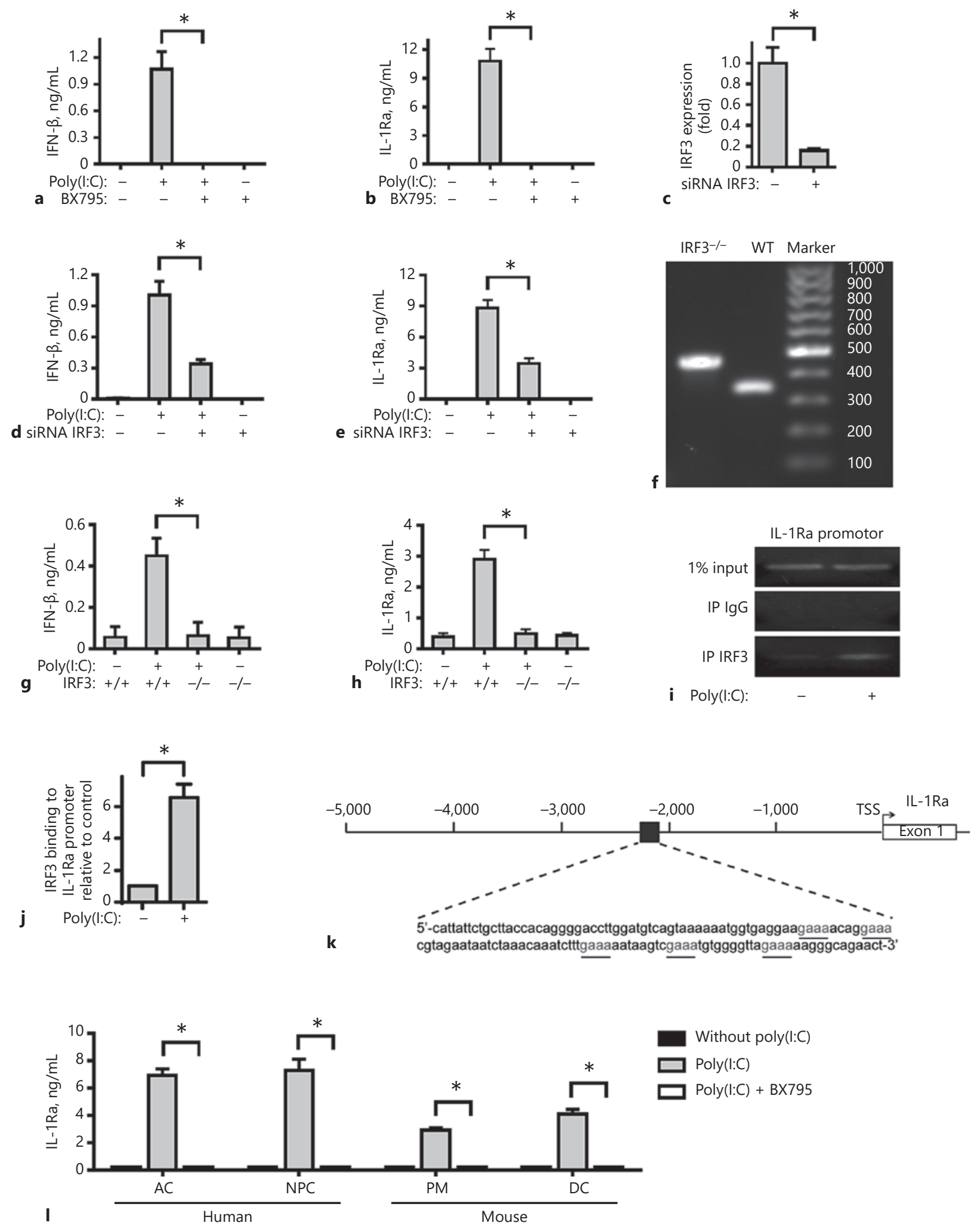

(For legend see next page.)

The Intrinsic Anti-Inflammatory Function of TLR3
J Innate Immun 2020;12:304-320 DOI: $10.1159 / 000504321$ 
Induction of IL-1Ra by TLR3 Activation Is Dependent on Activation of IRF3

Engagement of TLR3 by poly(I:C) can initiate the TRIF-dependent signaling by recruiting TRAF3 to activate TBK1 and IKKe, leading to activation of IRF3 [30]. To examine the role of TRIF-dependent signaling in poly(I:C)-induced IL-1Ra expression, primarily cultured human FLS were pre-treated with, or without BX795 (an inhibitor of TBK1 and $\mathrm{IKK \varepsilon}$ ) and stimulated with poly(I:C). We found that BX795 treatment completely abrogated the poly(I:C)-induced IFN- $\beta$ and IL-1Ra expression (Fig. 4a, b), suggesting that the TLR3-mediated TRIF/TRAF3/TBK1/IKKE-dependent IRF3 activation may be crucial for poly(I:C)-induced IL-1Ra expression in FLS. Indeed, knockdown of IRF3 by its specific siRNA significantly mitigated IRF3 expression (Fig. 4c) and the poly(I:C)-induced IFN- $\beta$ and IL-1Ra expression (Fig. $4 \mathrm{~d}$, e). Furthermore, the primarily cultured FLS from wildtype and IRF3 ${ }^{-1-}$ mice (Fig. $4 \mathrm{f}$ ) were stimulated with or without poly(I:C) for $24 \mathrm{~h}$. While poly(I:C) effectively stimulated IL-1Ra expression in FLS from wild-type mice, the same stimulation failed to stimulate IFN- $\beta$ and IL$1 \mathrm{Ra}$ expression in FLS from IRF3 ${ }^{-/}$mice (Fig. 4g, h). ChIP assay showed that IRF3 bound to the IL-1Ra promoter (Fig. 4i, j), and this binding was enhanced by treating cells with poly(I:C). Sequencing analysis of the IL-1Ra promoter revealed putative IRF3-binding sites in the $5^{\prime}$ untranslated region (Fig. 4k) of the IL-1Ra gene. These data suggested that IRF3 directly binds to the IL-1Ra promoter and promotes IL-1Ra expression in response to TLR3 activation. Similarly, pre-treatment with BX795 also abolished the poly(I:C)-induced IL-1Ra in primarily cultured human AC and NPC, and mouse PM and DC in vitro (Fig. 4l). Therefore, induction of IL-1 Ra by poly(I:C) appeared to depend on TLR3-mediated TRIF/TRAF3/

Fig. 4. IL-1Ra induced by TLR3 activation was dependent on activation of IRF3. Human FLS were pre-treated with BX795 (1 $\mu \mathrm{M})$ and then stimulated by poly(I:C) for 8 or $24 \mathrm{~h}$. The concentrations of IFN- $\beta$ (a) and IL-1Ra (b) in the supernatants of cultured cells were determined with ELISA. Human FLS were treated with siRNA IRF3 or siRNA NC for $48 \mathrm{~h}$. The cells were harvested and the levels of human IRF3 mRNA expression were measured by realtime PCR (c). Downregulation of human IRF3 expression is compared with siRNA NC group. Human FLS were pre-treated with siRNA IRF3 or siRNA NC for $48 \mathrm{~h}$ and then stimulated by poly(I:C) for 8 or $24 \mathrm{~h}$. The concentrations of IFN- $\beta$ (d) and IL-1Ra (e) in the supernatants of cultured cells were determined with ELISA. WT (350 bp) and IRF3 ${ }^{-/-}$(450 bp) mice were identified by PCR (f). FLS from WT or IRF3 ${ }^{-1-}$ mice were stimulated by poly(I:C) for 8 or $24 \mathrm{~h}$. The concentrations of IFN- $\beta$ (g) and IL-1Ra (h) in the su-

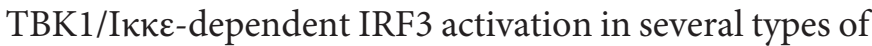
cells.

\section{Induction of IL-1Ra by TLR3 Activation Is Dependent} on the NF- $\kappa B$ and PI3K-Akt Signaling and Negatively Regulated by the ERK-MSK Signaling

To examine the influence of other signaling on the poly(I:C)-induced IL-1Ra, primarily cultured human FLS were pre-treated with BMS-345541 (an inhibitor of IкB), LY294002 (an inhibitor of PI3K), SB415286 (an inhibitor of GSK-3), PD184352 (an inhibitor of the MEK), SB747651A (an inhibitor of the MSK) and stimulated with poly(I:C). We found that BMS-345541, LY294002 or SB415286 attenuated the poly(I:C)-induced NF- $\kappa B$ activation (Fig. 5a), Akt (Fig. 5f) or GSK-3 $\beta$ (Fig. 5k) phosphorylation, but did not affect viability of FLS in vitro (Fig. 5b, g, l). More importantly, the blocking of NF- $\kappa \mathrm{B}$ signaling almost completely abolished poly(I:C)-stimulated IL-1Ra, IFN- $\beta$, and IL- 6 expression (Fig. $5 \mathrm{c}-\mathrm{e}$ ). However, the blocking of PI3K-Akt signaling only significantly mitigated the poly(I:C)-stimulated IL-1Ra and IFN- $\beta$, but not IL-6 (Fig. $5 \mathrm{~h}-\mathrm{j}, \mathrm{m}-\mathrm{o}$ ).

Further analysisindicated that PD 184352 or SB747651A blocked the activation of ERK1/2 or MSK1/2 (Fig. 6a, k), but did not affect viability of FLS in vitro (Fig. 6b, 1). It is interesting to note that the blocking of ERK1/2 activation significantly increased the poly(I:C)-stimulated IL-1Ra and IFN- $\beta$ expression, but did not change the level of IL- 6 (Fig. $6 \mathrm{c}-\mathrm{e}$ ). A similar pattern of IL-1Ra, IFN- $\beta$, and IL-6 was detected in the MSK1/2 silencing cells. Knockdown of MSK1 and MSK2 by specific siRNA significantly mitigated MSK1 and MSK2 expression (Fig. 6f, g), but increased the poly(I:C)-induced IFN- $\beta$ and IL-1Ra expression and did not affect IL-6 level (Fig. 6h-j). However, the blocking of MSK1/2 activation by SB747651A did not affect the poly(I:C)-stimulated IL-1Ra, IFN- $\beta$, and IL-6 (Fig. 6m-

pernatants of cultured cells were determined with ELISA. Human FLS were treated with poly(I:C) for $24 \mathrm{~h}$. ChIP assay showed that IRF3 bound to the IL-1Ra gene promoter. The binding was increased in poly(I:C)-treated FLS (i, j). Putative IRF3-binding sites upstream of the $5^{\prime}$ UTR of the IL-1Ra gene are shown in $\mathbf{k}$. Human AC and NPC, mouse PM and DC were pre-treated with BX795 $(1 \mu \mathrm{M})$ for $1 \mathrm{~h}$ and stimulated by poly(I:C) for $24 \mathrm{~h}$. The concentrations of IL-1Ra in the supernatants of cultured cells were determined with ELISA (I). Results are presented as mean \pm SEM $(n=$ 5 per group) from 3 separate experiments. ${ }^{*} p<0.05$ versus the group with poly(I:C) and vehicle. IL-1Ra, IL-1 receptor antagonist; TLR3, toll-like receptor 3; IRF3, interferon regulatory factor 3; AC, articular chondrocytes; NPC, nucleus pulposus cells; PM, peritoneal macrophages; DC, dendritic cells. 


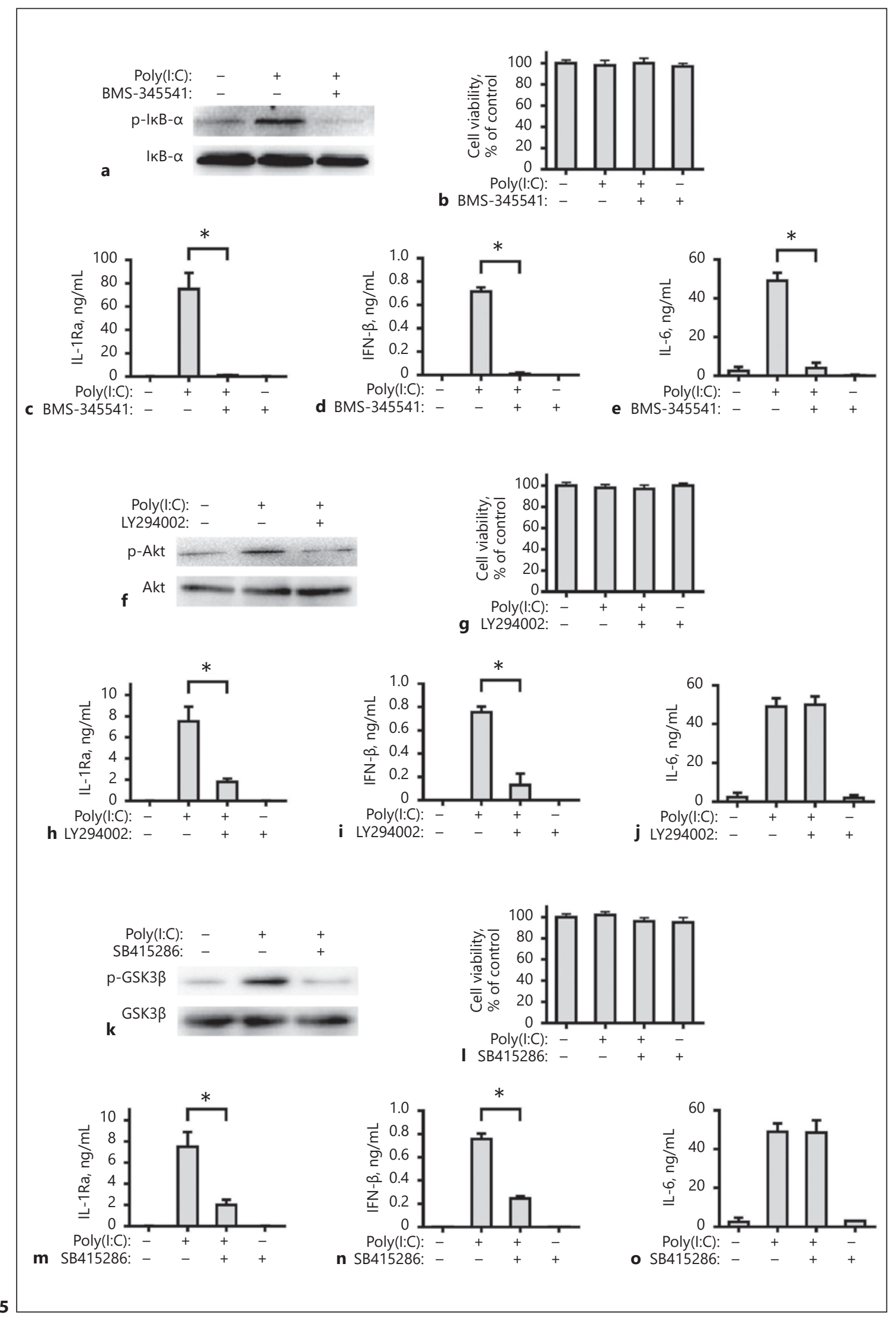

(For legend see next page.) 
o). Together, these results indicated that the induction of IL-1Ra expression by poly(I:C) was dependent on the NF$\kappa \mathrm{B}$ signaling and PI3K/Akt signaling, but negatively regulated by the ERK-MSKs signaling.

\section{Induction of IL-6 but Not IL-1Ra by TLR3 Activation} Is Regulated by the p38 MAPK Signaling

The p38 MAPK signaling was also activated by poly(I:C) through TLR3 activation. Our results showed that when pre-treated with SB203580, an inhibitor of $\mathrm{p} 38$ MAPK, attenuated the poly(I:C)-induced p38 MAPK activation (Fig. 7a), but did not affect viability of FLS in vitro (Fig. 7b). The blocking of p38 MAPK signaling did not affect poly(I:C)-stimulated IL-1Ra and IFN- $\beta$ expression, but significantly mitigated IL-6 expression (Fig. 7c-e), indicating that induction of IL- 6 but not IL- 1 Ra and IFN- $\beta$ expression by TLR3 activation is regulated by the $\mathrm{p} 38$ MAPK signaling.

\section{IL-1Ra Induced by Poly(I:C) or Sendai Virus Was} Dependent on TLR3 and IRF3 in vivo

To understand the importance of TLR3 and IRF3 in IL-1 Ra expression in vivo, TLR $^{-/-}, \mathrm{IRF}^{-/-}$and wild-type $\mathrm{C} 57 \mathrm{BL} / 6$ mice were treated intraperitoneally with poly(I:C) or Sendai virus. One day later, their blood samples were collected and the levels of serum IL-1Ra in individual mice were determined by ELISA. Treatment with poly(I:C) or Sendai virus significantly elevated the levels of serum IL-1Ra in the wild-type, but not in TLR $^{-1-}$ and IRF3 ${ }^{-/-}$mice (Fig. 8). Therefore, induction of IL-1Ra by poly(I:C) or Sendai virus is dependent on TLR3 and IRF3 in vivo.

\section{Discussion}

In this study, we found that IL-1Ra expression was induced by poly(I:C) through TLR3 activation in various types of cells, including FLS, AC, NPC, PM, and DC, but not in T cells, B cells, DF, BMSC, WI-38, MRC-5, NCIH358, NCI-H460, SH-SY5Y, and BV2. Hence, TLR3 acti-

Fig. 5. Induction of IL-1Ra expression by TLR3 activation is dependent on the NF- $\kappa \mathrm{B}$ and PI3K-Akt signaling. Human FLS were pre-treated with BMS-345541 (10 $\mu \mathrm{M})$, LY294002 (25 $\mu \mathrm{M})$ or SB415286 $(25 \mu \mathrm{M})$ for $1 \mathrm{~h}$. Subsequently, the cells were stimulated with poly(I:C) for $30 \mathrm{~min}$ and the relative levels of IкBa (a), Akt (f), and GSK3 $\beta$ (k) expression and phosphorylation in the different groups of FLSs were measured by Western blot assays. Human FLS were pre-treated with BMS-345541 (10 $\mathrm{MM}, \mathbf{b}-\mathbf{e})$, LY294002 (25 vation by poly(I:C) induces IL-1Ra expression in several types of cells with different genetic backgrounds. Previous studies reveal that TLR3 can recognize dsRNA and plays an important role in innate immune responses during virus infection by $[1,2]$. However, other studies reveal the detrimental contribution of TLR3 in viral pathogenesis [6]. TLR3 is localized in the endosomal membrane and recognizes extracellular dsRNA after endocytosis [43]. The intracellular distribution of TLR3 makes it disadvantaged to antivirus. Recent studies have showed that TLR3 can be activated by endogenous dsRNA, including natural dsRNAs [44], and RNAs released from necrotic cells [7, 45], damaged tissues [10] and small nuclear RNA [46]. Hence, TLR3 also acts as the sensor of tissue necrosis during the process of acute inflammation. Previous studies have reported MDA5 and RIG-I also recognize the intracytoplasmic viral dsRNA [3-5]. $\mathrm{MDA}^{-/-}$and $\mathrm{RIG}^{-\mathrm{I}^{-/}}$ mice are highly susceptible to infection with RNA viruses compared to control mice, implicating MDA5 and RIG-I are critical for host antiviral responses [47]. We found that induction of IL-1Ra expression by poly(I:C) was dependent on TLR3, but independent of MDA5 and RIG-I. Similarly, treatment with poly(I:C) also induced anti-inflammatory IL-27, IL-36Ra, and IL-37 and pre-treatment with TLR3 inhibitor of hydroxychloroquine completely abrogated the expression of anti-inflammatory cytokines induced by transfection dsRNA in FLS (data not shown). These data suggest that activation of TLR3 by endogenous dsRNA may be crucial for regulating inflammation, while the activation of MDA5/RIG-I by viral dsRNAs may predominantly mediate antiviral responses.

IL- $1 \beta$ and IFN- $\beta$ can induce IL-1Ra production in human FLS [28]. However, we found the activation of TLR3 by poly(I:C) to induce IL-1Ra expression was independent of endogenous and exogenous IFN- $\beta$ in FLS. Another study has showed that LPS-stimulated IL-1Ra mRNA transcription is blocked by cyclohexamide, the protein synthesis inhibitor, in macrophages [27], indicating that LPS may induce IL-1Ra expression through the cytokines induced by the TLR4-related signaling. However, we found that IL-1Ra mRNA transcription induced by

$\mu \mathrm{M}, \mathbf{g}-\mathbf{j})$ or SB415286 $(25 \mu \mathrm{M}, \mathbf{I}-\mathbf{o})$ for $1 \mathrm{~h}$ and stimulated by poly(I:C) for $8 \mathrm{~h}$ or $24 \mathrm{~h}$. The cell viability was measured by CCK8 assay. The concentrations of IL-1Ra, IFN- $\beta$, and IL- 6 in the culture supernatants were determined with ELISA. Results are presented as mean \pm SEM ( $n=5$ per group) from 3 separate experiments. ${ }^{*} p<0.05$ versus the group with poly(I:C) and vehicle. IL, interleukin; IL-1Ra, IL-1 receptor antagonist. 

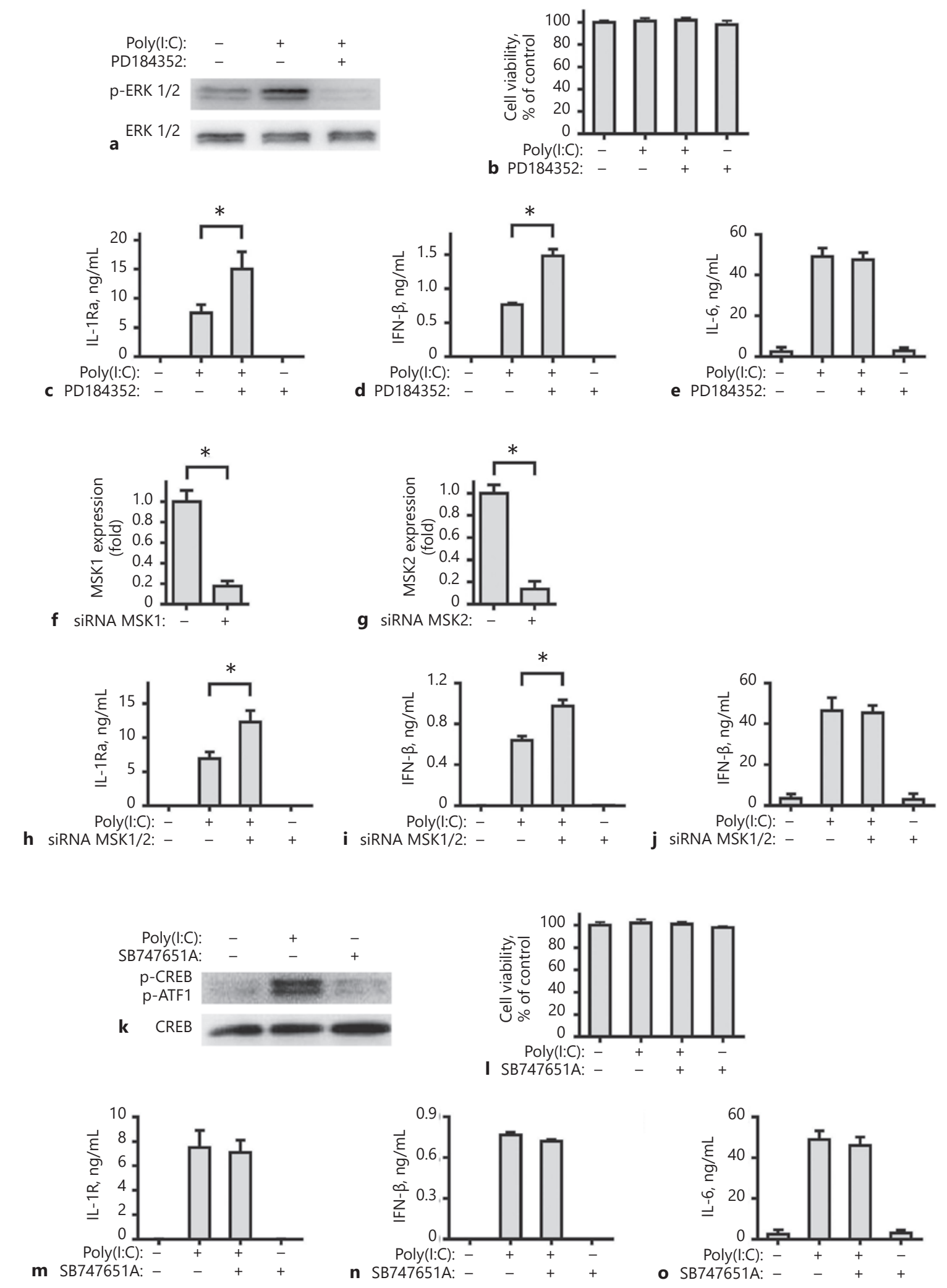

6

m SB747651A:

n SB747651A:

o SB747651A:

(For legend see next page.) 
poly(I:C) was significantly enhanced by blockage of protein synthesis in FLS. Our data suggest that the activation of TLR3-related signaling to induce IL-1Ra mRNA transcription may be different from that of TLR4 activationinduced IL-1Ra expression. Although poly(I:C) treatment induced IFN- $\beta$ and proinflammatory cytokines production in FLS, these cytokines may be inessential to enhance IL-1Ra expression following poly(I:C) stimulation in FLS.

It has been reported that the activation of TLR3 can induce anti-inflammatory IL-10 [12]. However, TLR3 activation protects against DSS-induced acute colitis, independent of IL-10 [16]. In our experiment condition, we found that treatment with poly(I:C) stimulated high levels of IL-1 Ra, but not IL-10 in human FLS, indicating that the protection of TLR3 activation might be dependent on IL-1Ra or IL-10 in different models.

The previous study showed that an addition of poly(I:C) to RL95-2 cells (an endometrial cell line) significantly increased the production of IL-1 Ra [48]. TLR4 activation can activate the NF- $\kappa \mathrm{B}$, ERK-MSKs, and PI3KAkt signaling to induce IL-1Ra expression through transcriptional factors of NF- $\kappa B$, CREB and ATF1 [27, 49]. Leptin can through its receptor activate the NF- $\kappa \mathrm{B}$ and ERK to induce IL-1Ra expression [50]. IL-10 through ac-
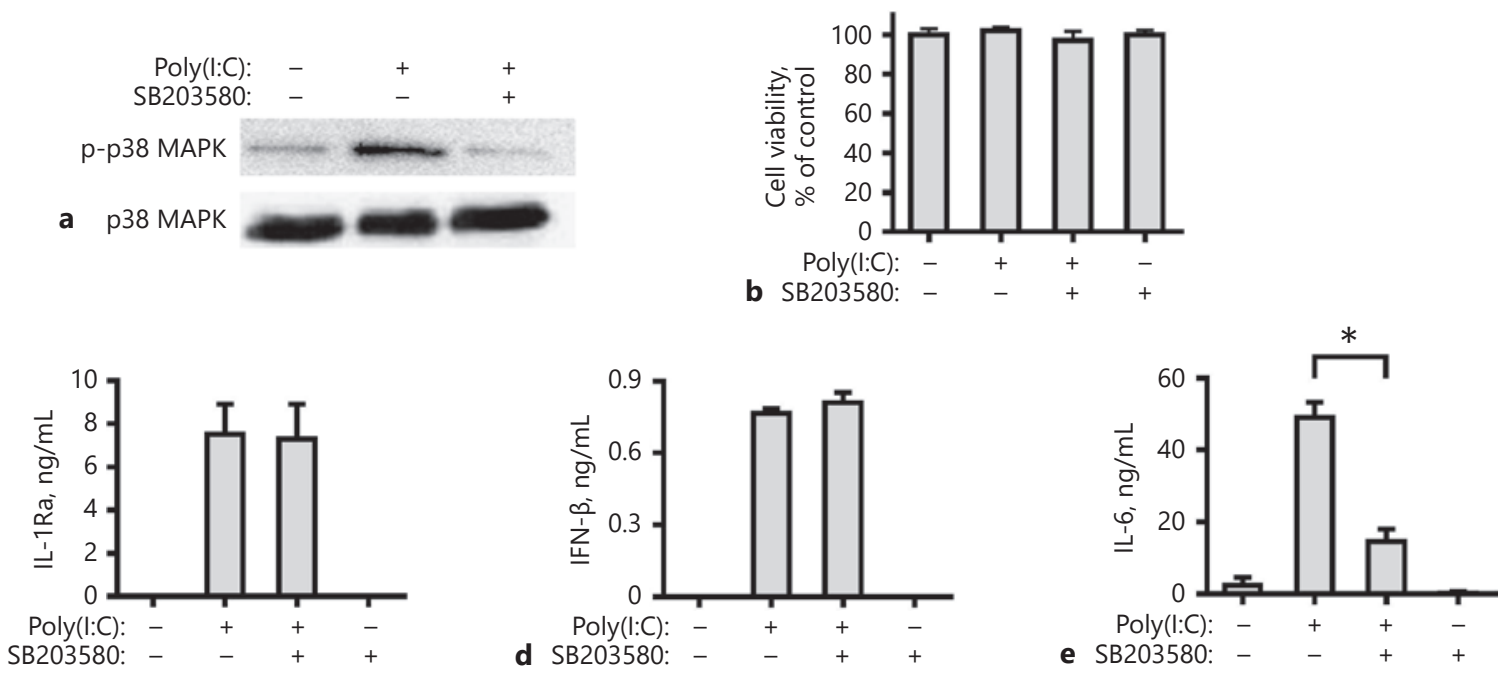

Fig. 7. Induction of IL- 6 but not IL-1Ra expression by TLR 3 activation is dependent on the p38 MAPK signaling. Human FLS were pre-treated with SB203580 (5 $\mu \mathrm{M})$ for $1 \mathrm{~h}$. Subsequently, the cells were stimulated with poly(I:C) for $30 \mathrm{~min}$ and the relative levels of p38 MAPK expression and phosphorylation in the different groups of FLS were measured by Western blot assays (a). Human FLS were pre-treated with SB203580 $(5 \mu \mathrm{M})$ for $1 \mathrm{~h}$ and stimulated by
poly(I:C) for $8 \mathrm{~h}$ or $24 \mathrm{~h}$. The cell viability was measured by CCK8 assay (b). The concentrations of IL-1Ra (c), IFN- $\beta$ (d), and IL-6 (e) in the culture supernatants were determined with ELISA. Results are presented as mean \pm SEM ( $n=5$ per group) from 3 separate experiments. ${ }^{*} p<0.05$ versus the group with poly(I:C) and vehicle. IL, interleukin; IL-1Ra, IL-1 receptor antagonist.
Fig. 6. Induction of IL-1Ra expression by TLR3 activation is negatively regulated by the ERK-MSKs signaling. Human FLS were pre-treated with PD184352 $(2 \mu \mathrm{M})$ or SB747651A $(10 \mu \mathrm{M})$ for $1 \mathrm{~h}$. Subsequently, the cells were stimulated with poly(I:C) for $30 \mathrm{~min}$ and the relative levels of ERK 1/2 (a) and CREB (k) expression and phosphorylation in the different groups of FLSs were measured by Western blot assays. Human FLS were pre-treated with PD184352 $(2 \mu \mathrm{M}, \mathbf{b}-\mathbf{e})$ or SB747651A $(10 \mu \mathrm{M}, \mathbf{I}-\mathbf{o})$ for $1 \mathrm{~h}$ and stimulated by poly(I:C) for $8 \mathrm{~h}$ or $24 \mathrm{~h}$. The cell viability was measured by CCK8 assay. The concentrations of IL-1Ra, IFN- $\beta$ and IL- 6 in the culture supernatants were determined with ELISA. Human FLS were treated with siRNA MSK1 (f), siRNA MSK2 (g), or siRNA NC for $48 \mathrm{~h}$. The cells were harvested and the levels of human MSK1 and MSK2 mRNA expression were measured by real-time PCR. Downregulation of human MSK1 and MSK2 expression are compared with the siRNA NC group. Human FLS were pre-treated with siRNA MSK1 and MSK2, or siRNA NC for $48 \mathrm{~h}$ and stimulated by poly(I:C) for $8 \mathrm{~h}$ or $24 \mathrm{~h}$. The concentrations of IL-1Ra (h), IFN- $\beta$ (i), and IL-6 (j) in the culture supernatants were determined with ELISA. Results are presented as mean $\pm \operatorname{SEM}(n=5$ per group) from 3 separate experiments. ${ }^{*} p<0.05$ vs. the group with poly(I:C) and vehicle. IL, interleukin; IL-1Ra, IL-1 receptor antagonist. 
Fig. 8. Induction of IL-1Ra expression by poly(I:C) and Sendai virus infection is dependent on TLR3 and IRF3 in vivo. WT, $\mathrm{TLR}^{-/-}$, and IRF3 ${ }^{-/-}$mice were treated intraperitoneally with poly(I:C; $10 \mathrm{mg} / \mathrm{kg}$ in sterile endotoxin-free physiological saline, a, b) or Sendai virus (100 HA units/mL, c, d) for $24 \mathrm{~h}$. The level of serum IL-1Ra was measured by ELISA. Results are presented as individual mean values of each mouse ( $n=8$ per group). The lines indicate the mean value for each group. ${ }^{*} p<0.05 \mathrm{vs}$. the WT mice group treated with poly(I:C) or Sendai virus. SenV, Sendai virus; IL-1Ra, IL-1 receptor antagonist; TLR3, toll-like receptor 3; IRF3, interferon regulatory factor 3 .

Fig. 9. Induction of IL-1Ra by dsRNA in FLS. The TLR3 is activated by extracellular virus- or host-derived structured RNA by endocytosis. The activated TLR3 recruits WDFY1 and TRIF, which further recruit TRAF3, PI3K, and TRAF6. The TRAF3 and PI3K activates transcription factor IRF3 while the TRAF6 activates the NF- $\kappa \mathrm{B}$, ERK-MSKs, p38 MAPK and JNK pathways though the TAK1 complex. IRF3 and NF$\kappa \mathrm{B}$ induce the expression of anti-proinflammatory cytokine IL-1Ra and type I IFN, while CREB and ATF1 negatively regulate the IL-1Ra and type I IFN production. Simultaneously, the NF- $\mathrm{KB}$ and AP-1 induce proinflammatory cytokine production. IL-1Ra, IL-1 receptor antagonist; TLR3, toll-like receptor 3; IRF3, interferon regulatory factor 3 .
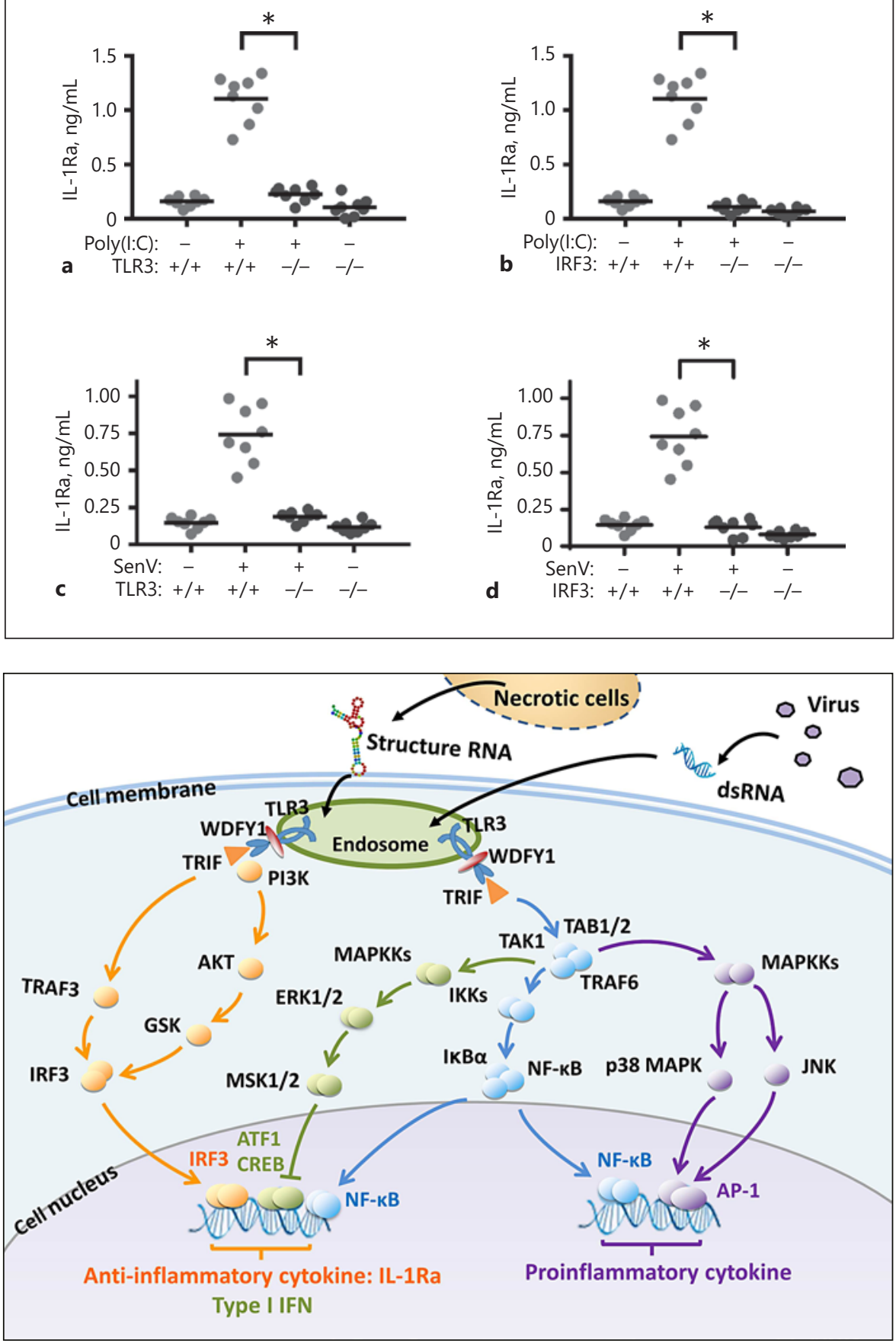

tivating the STAT3 [51] and IL-4 through activating the STAT6 [52] induce IL-1Ra expression. Furthermore, activation of TLR3 by dsRNA can also activate transcriptional factors of IRFs, NF- $\kappa$ B, CREB, ATF1, and AP-1 [1, $2,11]$. However, IL-1 Ra protein levels were $60 \mathrm{pg} / \mathrm{mL}$ in the control group (without poly[I:C] stimulation) and $140 \mathrm{pg} / \mathrm{mL}$ in the poly(I:C) stimulation group and activa- tion of MAPK was induced only by TLR 3 activation, not NF- $\kappa B$ in previous study [48]. IL-1Ra protein levels were $2 \mathrm{pg} / \mathrm{ml}$ in the control group (without poly[I:C] stimulation) and $8,000 \mathrm{pg} / \mathrm{mL}$ in poly(I:C) stimulation group in our study. We found that activation of TLR3 by poly(I:C) to induce IL-1Ra and IFN- $\beta$ was dependent on the IRF3, $\mathrm{NF}-\kappa \mathrm{B}$, and PI3K-Akt signaling, and negatively regulated 
by the EMK-MSKs signaling, but was independent of the p38 MAPK signaling in FLS, different from previous studies. The downstream signaling of TLR3 activation is shown in Figure 9. Indeed, the IL-1Ra promoter region contains binding sites for the NF- $\kappa \mathrm{B}$ [53] and IRF3 (Fig. 4i, j). Although binding sites for CREB and ATF1 do not exist in the IL-1Ra promoter, it is possible that the binding sites for CREB and ATF1 may be in the enhancer that separates from the promoter [27]. The AP-1 binding site exists in the promoters of proinflammatory cytokines. Therefore, our findings may provide new insights into regulation of anti-inflammatory IL-1Ra expression.

Currently, the recombinant IL-1Ra anakinra (Kineret, Amgen) has been used in the clinic and benefits patients with Still's disease, systemic-onset juvenile idiopathic arthritis, and several autoinflammatory disorders [54]. Given that IL-1Ra has a short half-life and new IL-1 antagonists are developing, new strategies to combine recombinant IL-1Ra and IL-1 antagonists may be valuable for intervention of inflammatory diseases. Actually, treatment with poly(I:C) induced sustained IL-1Ra expression in FLS, consistent with a previous report that treatment with poly(I:C) induces sustained levels of serum IL-1Ra in rhesus macaques [55]. Furthermore, pre-treatment with an inhibitor for the AP-1 effectively mitigated the poly(I:C)induced proinflammatory cytokine production, but did not affect anti-inflammatory cytokine in FLS. Because the balance of anti-inflammatory and proinflammatory cytokine responses is regulated precisely by different signal pathways, treatment with poly(I:C) to sustain high levels of serum IL-1Ra, together with an inhibitor of proinflammatory cytokine or its signaling, is reasonable strategies for treatment of inflammatory and autoimmune diseases.

When TLR3 is activated by virus dsRNA or endogenous dsRNA, activation of TLR3 induces anti-virus IFN- $\beta$ and anti-inflammatory IL- 1 Ra. IFN $-\beta$ mRNA transcripts were detected at $1 \mathrm{~h}$ and peaked at $3 \mathrm{~h}$ post stimulation, while IL-1Ra mRNA transcripts were detected at $8 \mathrm{~h}$ and peaked at $48 \mathrm{~h}$ post stimulation. Although the IFN- $\beta$ expression was induced earlier than IL-1Ra, activation of TLR3 induced both IFN- $\beta$ and IL-1Ra. We are interested in further testing how activation of TLR3 induces different dynamics of IFN- $\beta$ and IL-1Ra expression.

In summary, our data indicated that dsRNA induced IL-1Ra expression in several types of cells by activating the TLR3-related TRIP signaling, but independent of MDA5/RIG-I. Induction of IL-1Ra by poly(I:C) was independent of poly(I:C)-induced IFN- $\beta$ and proinflammatory cytokines. Activation of TLR3 by poly(I:C) induced IL-1Ra, which was dependent on the IRF3 and NF- $\kappa \mathrm{B}$ signaling, and regulated by the PI3K/Akt, ERK, and MSK, but not the p38MAPK signaling. More importantly, treatment with poly(I:C) or Sendai virus elevated serum IL-1Ra levels in mice, dependent on TLR3 and IRF3. Therefore, our findings may provide new insights into the intrinsic anti-inflammatory function of TLR3 and dsRNA-induced IL-Ra expression by TLR3 activation and its regulation and aid in design of new therapies for intervention of inflammatory and autoimmune diseases.

\section{Acknowledgments}

We thank the patients and staff of the First Teaching Hospital of Chengdu Medical College involved in the collection of human synovial, cartilage, skin and nucleus pulposus tissues.

\section{Statement of Ethics}

Animal experiments were conducted according to the Guide for the Care and Use of Medical Laboratory Animals (Ministry of Health, People's Republic of China) and approved by the Animal Care and Use Committee as well as the Ethics Committee of Chengdu Medical College (approval number: SYXK-[2015-196]).

Experiments involving human FLS, AC, DF, and NPCs or human synovial, cartilage, skin, and nucleus pulposus tissues were reviewed and approved by the Institutional Review Board. All donors provided written informed consent. All human-derived samples were anonymized before use.

\section{Disclosure Statement}

The authors have no conflicts of interest to disclose.

\section{Funding Sources}

The authors declare that this work was supported by National Natural Science Foundation of China (81302786, 81402944, 81871300), SichuanScienceand TechnologyProgram(2018JY0440, 2018JY0481), Scientific Research Fund of Sichuan Provincial Education Department (18ZA0143), and State Key Laboratory of Phytochemistry and Plant Resources in West China (P2018-KF03).

\section{Author Contributions}

Y.L. and Q.Z. conceived and designed the experiments. C.F.M., X.-Y.L., H.-J.G., H.S., and S.H. performed the experiments. Y.L., C.-F.M., and X.-Y.L. analyzed the data. L.-M.L., Y.-T.W., S.X.Y., and S.C. contributed reagents/materials/analysis tools. Y.L., H.L., and Q.Z. wrote the paper. All authors read and approved the final manuscript. 


\section{References}

1 Tatematsu M, Seya T, Matsumoto M. Beyond dsRNA: toll-like receptor 3 signalling in RNA-induced immune responses. Biochem J. 2014 Mar;458(2):195-201.

2 Alexopoulou L, Holt AC, Medzhitov R, Flavell RA. Recognition of double-stranded RNA and activation of NF-kappaB by Tolllike receptor 3. Nature. 2001 Oct;413(6857): 732-8.

3 Avril T, de Tayrac M, Leberre C, Quillien V. Not all polyriboinosinic-polyribocytidylic acids (Poly I:C) are equivalent for inducing maturation of dendritic cells: implication for alpha-type-1 polarized DCs. J Immunother. 2009 May;32(4):353-62.

4 Akira S, Uematsu S, Takeuchi O. Pathogen recognition and innate immunity. Cell. 2006 Feb;124(4):783-801.

5 Gürtler C, Bowie AG. Innate immune detection of microbial nucleic acids. Trends Microbiol. 2013 Aug;21(8):413-20.

6 Perales-Linares R, Navas-Martin S. Toll-like receptor 3 in viral pathogenesis: friend or foe? Immunology. 2013 Oct;140(2):153-67.

7 Brentano F, Schorr O, Gay RE, Gay S, Kyburz D. RNA released from necrotic synovial fluid cells activates rheumatoid arthritis synovial fibroblasts via Toll-like receptor 3. Arthritis Rheum. 2005 Sep;52(9):2656-65.

8 Kariko K, Ni H, Capodici J, Lamphier M, Weissman D. mRNA is an endogenous ligand for Toll-like receptor 3. J Biol Chem. 2004 Mar;279(13):12542-50.

9 Radwan M, Gavriilidis C, Robinson JH, Davidson $\mathrm{R}$, Clark IM, Rowan $\mathrm{AD}$, et al. Matrix metalloproteinase 13 expression in response to double-stranded RNA in human chondrocytes. Arthritis Rheum. 2013 May;65(5): 1290-301.

10 Nelson AM, Reddy SK, Ratliff TS, Hossain MZ, Katseff AS, Zhu AS, et al. dsRNA Released by Tissue Damage Activates TLR3 to Drive Skin Regeneration. Cell Stem Cell. 2015 Aug;17(2):139-51.

11 O’Neill LA, Golenbock D, Bowie AG. The history of Toll-like receptors - redefining innate immunity. Nat Rev Immunol. 2013 Jun;13(6) 453-60.

12 Cole JE, Navin TJ, Cross AJ, Goddard ME, Alexopoulou L, Mitra AT, et al. Unexpected protective role for Toll-like receptor 3 in the arterial wall. Proc Natl Acad Sci USA. 2011 Feb;108(6):2372-7.

13 Borysiewicz E, Doppalapudi S, Kirschman LT, Konat GW. TLR3 ligation protects human astrocytes against oxidative stress. J Neuroimmunol. 2013 Feb;255(1-2):54-9.

14 Patel AK, Hackam AS. Toll-like receptor 3 (TLR3) protects retinal pigmented epithelium (RPE) cells from oxidative stress through a STAT3-dependent mechanism. Mol Immunol. 2013 Jun;54(2):122-31.

15 Leonard WJ, O’Shea JJ. Jaks and STATs: biological implications. Annu Rev Immunol. 1998;16(1):293-322.
16 Vijay-Kumar M, Wu H, Aitken J, Kolachala VL, Neish AS, Sitaraman SV, et al. Activation of toll-like receptor 3 protects against DSSinduced acute colitis. Inflamm Bowel Dis. 2007 Jul;13(7):856-64.

17 Dinarello CA. Immunological and inflammatory functions of the interleukin-1 family. Annu Rev Immunol. 2009;27(1):519-50.

18 Garlanda C, Dinarello CA, Mantovani A. The interleukin-1 family: back to the future. Immunity. 2013 Dec;39(6):1003-18.

19 Boissier MC, Semerano L, Challal S, Saidenberg-Kermanac'h N, Falgarone G. Rheumatoid arthritis: from autoimmunity to synovitis and joint destruction. J Autoimmun. 2012 Sep;39(3):222-8.

20 Niki Y, Yamada H, Seki S, Kikuchi T, Takaishi $\mathrm{H}$, Toyama Y, et al. Macrophage- and neutrophil-dominant arthritis in human IL-1 alpha transgenic mice. J Clin Invest. 2001 May; 107(9):1127-35.

21 Iwakura Y. Roles of IL-1 in the development of rheumatoid arthritis: consideration from mouse models. Cytokine Growth Factor Rev. 2002 Aug;13(4-5):341-55.

22 Horai R, Saijo S, Tanioka H, Nakae S, Sudo K, Okahara A, et al. Development of chronic inflammatory arthropathy resembling rheumatoid arthritis in interleukin 1 receptor antagonist-deficient mice. J Exp Med. 2000 Jan; 191(2):313-20.

23 Akitsu A, Ishigame H, Kakuta S, Chung SH, Ikeda S, Shimizu K, et al. IL-1 receptor antagonist-deficient mice develop autoimmune arthritis due to intrinsic activation of IL-17-producing CCR2 $(+) \mathrm{V} \gamma 6(+) \gamma \delta \mathrm{T}$ cells. Nat Commun. 2015;6(1):7464.

24 Reddy S, Jia S, Geoffrey R, Lorier R, Suchi M, Broeckel U, et al. An autoinflammatory disease due to homozygous deletion of the IL$1 R N$ locus. N Engl J Med. 2009 Jun;360(23): 2438-44.

25 Aksentijevich I, Masters SL, Ferguson PJ, Dancey P, Frenkel J, van Royen-Kerkhoff A, et al. An autoinflammatory disease with deficiency of the interleukin-1-receptor antagonist. N Engl J Med. 2009 Jun;360(23):242637.

26 Kalliolias GD, Liossis SN. The future of the IL-1 receptor antagonist anakinra: from rheumatoid arthritis to adult-onset Still's disease and systemic-onset juvenile idiopathic arthriti. Expert Opin Investig Drugs. 2008 Mar; 17(3):349-59.

27 Darragh J, Ananieva O, Courtney A, Elcombe $\mathrm{S}$, Arthur JS. MSK1 regulates the transcription of IL-1ra in response to TLR activation in macrophages. Biochem J. 2010 Feb;425(3): 595-602.

28 Palmer G, Mezin F, Juge-Aubry CE, PlaterZyberk C, Gabay C, Guerne PA. Interferon beta stimulates interleukin 1 receptor antagonist production in human articular chondrocytes and synovial fibroblasts. Ann Rheum Dis. 2004 Jan;63(1):43-9.
29 Maedler K, Sergeev P, Ehses JA, Mathe Z, Bosco D, Berney T, et al. Leptin modulates beta cell expression of IL-1 receptor antagonist and release of IL-1beta in human islets. Proc Natl Acad Sci USA. 2004 May;101(21):813843.

30 Doyle S, Vaidya S, O'Connell R, Dadgostar H, Dempsey $\mathrm{P}, \mathrm{Wu} \mathrm{T}$, et al. IRF3 mediates a TLR3/TLR4-specific antiviral gene program. Immunity. 2002 Sep;17(3):251-63.

31 Nourbakhsh M, Hauser H. Constitutive silencing of IFN-beta promoter is mediated by NRF (NF-kappaB-repressing factor), a nuclear inhibitor of NF-kappaB. EMBO J. 1999 Nov; 18(22):6415-25.

32 Jiang Z, Mak TW, Sen G, Li X. Toll-like receptor 3-mediated activation of NF-kappaB and IRF3 diverges at Toll-IL-1 receptor domaincontaining adapter inducing IFN-beta. Proc Natl Acad Sci USA. 2004 Mar;101(10):35338.

33 Tarassishin L, Suh HS, Lee SC. Interferon regulatory factor 3 plays an anti-inflammatory role in microglia by activating the PI3K/Akt pathway. J Neuroinflammation. 2011 Dec; 8(1): 187 .

34 Rosengren S, Corr M, Firestein GS, Boyle DL. The JAK inhibitor CP-690,550 (tofacitinib) inhibits TNF-induced chemokine expression in fibroblast-like synoviocytes: autocrine role of type I interferon. Ann Rheum Dis. 2012 Mar;71(3):440-7.

35 Dai SM, Shan ZZ, Nishioka K, Yudoh K. Implication of interleukin 18 in production of matrix metalloproteinases in articular chondrocytes in arthritis: direct effect on chondrocytes may not be pivotal. Ann Rheum Dis. 2005 May;64(5):735-42.

36 Clark RA, Kupper TS. IL-15 and dermal fibroblasts induce proliferation of natural regulatory $\mathrm{T}$ cells isolated from human skin. Blood. 2007 Jan;109(1):194-202.

37 Gilbert HT, Hoyland JA, Millward-Sadler SJ. The response of human anulus fibrosus cells to cyclic tensile strain is frequency-dependent and altered with disc degeneration. Arthritis Rheum. 2010 Nov;62(11):3385-94.

38 Haynesworth SE, Goshima J, Goldberg VM, Caplan AI. Characterization of cells with osteogenic potential from human marrow. Bone. 1992;13(1):81-8.

39 Liu Y, Yang T, Li H, Li MH, Liu J, Wang YT, et al. BD750, a benzothiazole derivative, inhibits $\mathrm{T}$ cell proliferation by affecting the JAK3/STAT5 signalling pathway. Br J Pharmacol. 2013 Feb;168(3):632-43.

40 Langdon C, Kerr C, Hassen M, Hara T, Arsenault AL, Richards CD. Murine oncostatin M stimulates mouse synovial fibroblasts in vitro and induces inflammation and destruction in mouse joints in vivo. Am J Pathol. 2000 Oct; 157(4):1187-96.
The Intrinsic Anti-Inflammatory

Function of TLR3
I Innate Immun 2020;12:304-320

DOI: $10.1159 / 00050432$ 
41 Inaba K, Inaba M, Romani N, Aya H, Deguchi M, Ikehara S, et al. Generation of large numbers of dendritic cells from mouse bone marrow cultures supplemented with granulocyte/ macrophage colony-stimulating factor. J Exp Med. 1992 Dec;176(6):1693-702.

42 Pisegna S, Pirozzi G, Piccoli M, Frati L, Santoni A, Palmieri G. p38 MAPK activation controls the TLR3-mediated up-regulation of cytotoxicity and cytokine production in human NK cells. Blood. 2004 Dec;104(13):4157-64.

43 Kawasaki T, Kawai T. Toll-like receptor signaling pathways. Front Immunol. 2014;5:461.

44 Portal MM, Pavet V, Erb C, Gronemeyer H. Human cells contain natural double-stranded RNAs with potential regulatory functions. Nat Struct Mol Biol. 2015 Jan;22(1):89-97.

45 Cavassani KA, Ishii M, Wen H, Schaller MA, Lincoln PM, Lukacs NW, et al. TLR3 is an endogenous sensor of tissue necrosis during acute inflammatory events. J Exp Med. 2008 Oct;205(11):2609-21.

46 Bernard JJ, Cowing-Zitron C, Nakatsuji T, Muehleisen B, Muto J, Borkowski AW, et al. Ultraviolet radiation damages self noncoding RNA and is detected by TLR3. Nat Med. 2012 Aug;18(8):1286-90.
47 Kato H, Takeuchi O, Sato S, Yoneyama M, Yamamoto M, Matsui K, et al. Differential roles of MDA5 and RIG-I helicases in the recognition of RNA viruses. Nature. 2006 May; 441(7089):101-5.

48 Montazeri M, Sanchez-Lopez JA, Caballero I, Maslehat Lay N, Elliott S, Fazeli A. Interleukin-1 receptor antagonist mediates toll-like receptor 3-induced inhibition of trophoblast adhesion to endometrial cells in vitro. Hum Reprod. 2016 Sep;31(9):2098-107.

49 Rehani K, Wang H, Garcia CA, Kinane DF, Martin M. Toll-like receptor-mediated production of IL-1Ra is negatively regulated by GSK3 via the MAPK ERK1/2. J Immunol. 2009 Jan;182(1):547-53.

50 Dreyer MG, Juge-Aubry CE, Gabay C, Lang U, Rohner-Jeanrenaud F, Dayer JM, et al Leptin activates the promoter of the interleukin-1 receptor antagonist through p42/44 mitogen-activated protein kinase and a composite nuclear factor kappa B/PU.1 binding site. Biochem J. 2003 Mar;370(Pt 2):591-9.
51 Carl VS, Gautam JK, Comeau LD, Smith MF Jr. Role of endogenous IL-10 in LPS-induced STAT3 activation and IL-1 receptor antagonist gene expression. J Leukoc Biol. 2004 Sep; 76(3):735-42

52 Ohmori Y, Smith MF Jr, Hamilton TA. IL4 -induced expression of the IL-1 receptor antagonist gene is mediated by STAT6. J Immunol. 1996 Sep;157(5):2058-65.

53 Smith MF Jr, Carl VS, Lodie T, Fenton MJ Secretory interleukin-1 receptor antagonist gene expression requires both a PU.1 and a novel composite NF-kappaB/PU.1/ GAbinding protein binding site. $\mathrm{J}$ Biol Chem. 1998 Sep;273(37):24272-9.

54 Burger D, Dayer JM, Palmer G, Gabay C. Is IL-1 a good therapeutic target in the treatment of arthritis? Best Pract Res Clin Rheumatol. 2006 Oct;20(5):879-96.

55 Sariol CA, Martinez MI, Rivera F, Rodriguez IV, Pantoja P, Abel K, et al. Decreased dengue replication and an increased anti-viral humoral response with the use of combined Toll-like receptor 3 and 7/8 agonists in macaques. PLoS One. 2011;6(4):e19323. 